\title{
Biofficacy of Entomopathogenic Nematode, Heterorhabditis indica against White Grub, Phyllognathus dionysius Feb. Under Laboratory Condition
}

\author{
Balkrishna Rathour ${ }^{1}$, Dr. Pandurang B. Mohite ${ }^{2}$, Rahul Bhaskar Gite ${ }^{3}$ \\ Department of Entomology, College of Agriculture, Kolhapur, MPKV, Rahuri
}

\begin{abstract}
An investigation was carried out to assess the efficiency of Heterorhabditis indica against white grub, Phyllognathus dionysius Feb. in laboratory condition. In laboratory bioassay studies Entomopathogenic nematode Heterorhabditis indica was tested for their Pathogenicity against first, second and third instar grubs of P. dionysius. The treatments $\mathrm{H}$. indica @ $100 \mathrm{IJs} \mathrm{mt}^{-1}$ for first instar grubs, 150 $I J s \mathrm{ml}^{-1}$ for second instar grubs and $250 \mathrm{IJS} \mathrm{m}^{-1}$ for third instar grubs were found most effective in controlling P. dionysius. The treatment of $H$. indica recorded 67.50 to 86.53 per cent mortality of first instar grubs at 7 DAT, 47.50 to 77.50 per cent mortality of second instar grubs at 7 DAT and 52.50 to 85.50 per cent mortality of third instar grubs at 15 DAT. H. indica also registered least LC 50 value, $44.15 \mathrm{IJs} \mathrm{m}^{-1}, 97.47$ $\mathrm{IJs} \mathrm{ml}^{-1}$ and $150.12 \mathrm{IJs} \mathrm{m}^{-1}$ for first, second and third instar grubs, respectively. We concluded that the increasing dose of Entomopathogenic nematodes showed increasing mortality and large size grub required higher dose of nematodes compare to small size grub.
\end{abstract}

Keywords: Phyllognathus dionysius, Heterorhabditis indica, Entomopathogenic nematode

\section{Introdution}

Sugarcane, Saccharum officinarum L. is one of the most important commercial crops of the tropical countries and is the main source of sugar for hundreds of years in the world. Globally, sugarcane is cultivated over an area of 25.4 million hectares with a production of 1794.3 million tones and productivity of 70.5 tonnes per hactere. India ranks seconds in both area and production of sugarcane next to Brazil (FAO, 2010). India's share in world production of sugar was 15.39 per cent in 2013-14 (Anonymous, 2015).

In India, nearly 228 insect and non- insect pests have been reported on the crop. About 125 species of insects are known to infest the sugarcane as major pests in various part of the world (Patil et al., 2004). Among them white grub has became the most important polyphagous pest causing serious damage to sugarcane. The white grubs were recognized as the most serious pests on sugarcane, groundnut, cereals, millets, pulses, vegetables and on plantation crops like coconut, areca nut, coffee and rubber (David and Nandgopal, 1986). Among the white grubs, Phyllognathus dionysius Fabricious has recently been reported as new pest and becoming threat to sugarcane, soybean and groundnut cultivation in the Western Maharashtra especially in Kolhapur and Sangli districts (Mohite, 2014). The species is abundant during June to August. The life cycle is annual (Bhawane et al., 2012). Several tactics have been adopted for the management of white grubs including cultural, mechanical, biological, chemical and integrated methods suggested by various workers.

The use of bio pesticides as a vital component in white grub management is economic viability, social acceptability and eco friendly in nature. Among these, biological control by using entomopathogenic nematodes holds promise. The Steinernematidae and Heterorhabditidae have received more attention because they posses many of the attributes of effective biological control agents (Grewal et al., 2005). Insect pests have been found susceptible to the entomopathogenic nematodes (EPNs) of family Heterorhabditidae and Steinernematidae species in India and abroad, resulting in their prospective role as biological agents (Kulkarni et al., 2008). EPNs have been studied extensively for the control of white grubs. Among the two entomopathogenic nematodes, $S$. glaseri and $H$. indica tested on different instars of white grubs, (Karunakar et al. 2000).

\section{Materials and Methods}

Insect culture: The grubs of $P$. dionysius of the first, second and third instar grub stages were collected from infested groundnut and soybean farmer field and from endemic pockets of Kolhapur district. Immediately after the collection of grubs, they were placed in sterile plastic vials with soil. Only one larva put into each vial and potato pieces and sugarcane roots which are disinfected for $10 \mathrm{~min}$ in 0.5 per cent sodium hypochloride solution were added to each vial as a diet. The larval culture maintained at $25 \pm 2^{\circ} \mathrm{C}$ and $65 \pm 5$ per cent R.H. were used for laboratory experiments.

Nematode culture: Entomopathogenic nematode Heterorhabditis indica was brought from National Institute of Plant Health Management, (NIPHM) Hydrabad in sponge formulation.

\section{Volume 4 Issue 12, December 2015}




\section{International Journal of Science and Research (IJSR) \\ ISSN (Online): 2319-7064 \\ Index Copernicus Value (2013): 6.14 | Impact Factor (2014): 5.611}

\section{Bioassy}

The suspension of $H$. indica prepared with dilution of nematode formulation in sterile diluted water. The doseresponse assay included nematode concentration of 25, 50, 75, $100,150,200$ and $250 \mathrm{IJs} /$ grub were used. The larvae were treated with nematode suspension and then treated individual larvae transferred separately into a sterile vial and pieces of sugarcane or potato provided as food for grubs. A set of ten larvae with four replications of each concentration of nematode formulation and a control treated with distilled

To determine the $\mathrm{LC}_{50}$ of $H$. indica the first, second and third instar larvae of $P$. dionysius were employed. The mortality data were subjected to probit analysis (Finney, 1971). The $\mathrm{LC}_{50}$ values for different concentrations of EPNs were worked out in SPSS 7.5 software package.

Statistical analysis: Data on per cent mortality were corrected by Abbott's formula (Abbott, 1925). Data on infected grubs in laboratory experiment was subjected to arcsin transformations, these transformed data were subjected to analysis of variance.

\section{Results and Discussion}

Four different IJs concentrations of $H$. indica viz., 25, 50, 75, $100 \mathrm{IJs} \mathrm{ml}^{-1}$ were tested for determining the bioefficacy of $H$. indica on the first, second and third instar grubs of $P$. dionysius.

\section{Second instar}

The treatment with $150 \mathrm{IJs} \mathrm{ml}^{-1}$ was found to be the most significantly superior over the rest of the treatments and recorded 46.00 per cent mortality at 3 DAT. The observation recorded at 5 DAT the treatment with concentration $150 \mathrm{IJs}$ $\mathrm{ml}^{-1}$ recorded 62.50 per cent grub mortality which was significantly superior to the rest of treatments. The treatment with concentration $150 \mathrm{IJs} \mathrm{ml}^{-1}$ recorded highest $(77.50$ per cent) grub mortality, which was significantly superior to the rest of treatments and all day observation. The $\mathrm{LC}_{50}$ value recorded for $H$. indica for second instar grub was $97.47 \mathrm{IJs} \mathrm{ml}^{-}$ ${ }^{1}$. Mortality was not observed in untreated control. The results presented in table and graph in Table 2 and Fig. 2 respectivly.

\section{Third instar}

The treatment with concentration $250 \mathrm{IJs} \mathrm{ml}^{-1}$ recorded 22.26 per cent mortality and it was significantly superior over other treatments at $3 \mathrm{DAT}$. The treatment with concentration $250 \mathrm{IJs}$ $\mathrm{ml}^{-1}$ recorded highest (47.50 per cent) grub mortality, which was found to be superior over other treatments when observation recorded at 5 DAT. The treatment with concentration $250 \mathrm{IJs} \mathrm{ml}^{-1}$ consistently recorded 65.50 per cent mortality which was significantly superior over the rest of treatments at 7 DAT. The treatment with concentration 250 IJs water was maintained. The sugarcane or potato pieces changed every day. The grubs kept at $25 \pm 2^{\circ} \mathrm{C}$ and $65 \pm 5$ per cent R.H. till death.

The grub mortality was recorded after the treatment an interval of 3, 5, 7 and 15 days after treatment. The exact time required to kill the test larva was strictly recorded. The cause of larval death was confirmed by body colour change of the cadaver which being evident due to the presence of symbiotic bacteria.

\section{First instar}

The treatment with concentration $100 \quad \mathrm{IJs} \quad \mathrm{ml}^{-1}$ was significantly superior over the other treatments and recorded 55.00 per cent grub mortality at 3 DAT. The treatment with concentration $100 \mathrm{IJs} \mathrm{ml}^{-1}$ was found to be most effective, recorded 74.50 per cent grub mortality and it was found to be significantly superior over all other treatments when the observations were recorded at 5 DAT. The 86.53 per cent mortality was observed in treatment with $100 \mathrm{IJs} \mathrm{ml}^{-1}$ when observations were recorded at 7 DAT which was superior to the rest of the treatment and all day's observation under test. The least (12.50 per cent) grub mortality was observed in untreated control at 7 DAT. The mortality 5 and 7 DAT in untreated control may be due to the handling of the grub at the time of observation and feeding them. The $\mathrm{LC}_{50}$ value recorded for $H$. indica for first instar grub was $44.16 \mathrm{IJs} \mathrm{ml}^{-1}$. The results presented in table and graph in Table 1 and Fig. 1 respectivly.

$\mathrm{ml}^{-1}$ Recorded highest (85.50 per cent) mortality, which was consistently superior over the rest of the treatments and all observation dates. The mortality was not observed in untreated control. The $\mathrm{LC}_{50}$ value recorded for $H$. indica for third instar grub was $150.12 \mathrm{IJs} \mathrm{ml}^{-1}$. The results presented in table and graph in Table 3 and Fig. 3 respectivly.

The efficacy of $H$. indica is in accordance with the observation made by Maneesakorn et al., (2010) who reported that $H$. indica strains were more virulent against the Japanese beetle, P. japonica with $\mathrm{LC}_{50}$ value of $136 \mathrm{IJs} \mathrm{ml}^{-1}$ at $5 \mathrm{DAT}$ under laboratory conditions. Gokce et al., (2014) reported 100 per cent mortality with 500 IJs. Their results indicated that mortality percent increase with the increasing dose of nematode.

When the grubs of Maladera insanabilis Brenske were exposed to $H$. bacteriophora (IJs) in soil, lower inoculation doses were necessary to kill the host $\left(\mathrm{LD}_{50}, 14090 \mathrm{IJs} / 100 \mathrm{~g}\right.$ soil/grub), host mortality occurred earlier ( $\mathrm{LT}_{50}, 5.65$ days) and more IJs were produced per cadaver of infected host (69840/grub; 607.30 IJs/mg host body weight. (Bhatnagar, 2011). These findings are comparable to the findings of present investigations and gave support the data. 


\section{International Journal of Science and Research (IJSR) \\ ISSN (Online): 2319-7064 \\ Index Copernicus Value (2013): 6.14 | Impact Factor (2014): 5.611}

Table 1: Evaluation of $H$. indica against first instar grubs of $P$. dionysius in laboratory experiment

\begin{tabular}{|c|c|c|c|c|}
\hline \multirow{2}{*}{$\begin{array}{c}\text { Treatment } \\
\text { No }\end{array}$} & \multirow{2}{*}{$\begin{array}{c}\text { Dose } \\
\text { IJs ml }^{-1}\end{array}$} & & \multicolumn{3}{|c|}{$\begin{array}{c}\text { Per cent grub mortality } \\
\text { DAT* }\end{array}$} \\
\cline { 3 - 5 } & & 3DAT & 5DAT & 7DAT \\
\hline $\mathrm{T}_{1}$ & 25 & $25.00(29.99)^{* *}$ & $45.00(42.13)$ & $67.50(55.25)$ \\
\hline $\mathrm{T}_{2}$ & 50 & $32.50(34.75)$ & $55.00(47.87)$ & $75.00(60.01)$ \\
\hline $\mathrm{T}_{3}$ & 75 & $40.00(39.23)$ & $57.50(49.32)$ & $80.50(63.80)$ \\
\hline $\mathrm{T}_{4}$ & 100 & $55.00(47.87)$ & $74.50(59.67)$ & $86.53(68.51)$ \\
\hline $\mathrm{T}_{5}$ & Untreated control & $0.00(0.00)$ & $7.50(15.88)$ & $12.50(20.69)$ \\
\hline & SE \pm & 0.68 & 0.79 & 0.96 \\
\hline & CD at $5 \%$ & 2.07 & 2.38 & 2.92 \\
\hline
\end{tabular}

*DAT: Days after treatment. **Figures in parentheses are arcsin transformed values.

Table 2: Evaluation of $H$. indica against second instar grubs of $P$. dionysius

\begin{tabular}{|c|c|c|c|c|}
\hline \multirow{2}{*}{$\begin{array}{c}\text { Treatment } \\
\text { No }\end{array}$} & \multirow{2}{*}{$\begin{array}{c}\text { Dose } \\
\text { IJs ml }^{-1}\end{array}$} & \multicolumn{3}{|c|}{ Per cent grub mortality } \\
\cline { 3 - 5 } & & 3DAT & 5DAT & 7DAT \\
\cline { 3 - 5 } & 50 & $17.50(24.71)^{* *}$ & $32.15(34.54)$ & $47.50(43.56)$ \\
\hline $\mathrm{T}_{1}$ & 75 & $25.00(29.98)$ & $42.50(40.68)$ & $55.00(47.87)$ \\
\hline $\mathrm{T}_{2}$ & 100 & $32.50(34.75)$ & $50.00(40.00)$ & $65.00(53.73)$ \\
\hline $\mathrm{T}_{3}$ & 150 & $46.00(42.70)$ & $62.50(52.24)$ & $77.50(61.69)$ \\
\hline $\mathrm{T}_{4}$ & Untreated control & $0.00(0.00)$ & $0.00(0.00)$ & $0.00(0.00)$ \\
\hline $\mathrm{T}_{5}$ & $\mathrm{SE} \pm$ & 0.68 & 0.57 & 0.60 \\
\hline & $\mathrm{CD}$ at $5 \%$ & 2.04 & 1.73 & 1.81 \\
\hline
\end{tabular}

*DAT: Days after treatment. **Figures in parentheses are arcsin transformed values.

Table 3: Evaluation of $H$. indica against third instar grubs of $P$. Dionysius

\begin{tabular}{|c|c|c|c|c|c|}
\hline \multirow{2}{*}{$\begin{array}{c}\text { Treatment } \\
\text { No }\end{array}$} & Dose & \multicolumn{4}{|c|}{ Per cent grub mortality DAT* } \\
\cline { 3 - 6 } IJs ml $^{-1}$ & 3DAT & 5DAT & 7DAT & 15DAT \\
\hline $\mathrm{T}_{1}$ & 100 & $7.50(15.82)^{* *}$ & $27.50(31.62)$ & $40.22(39.36)$ & $52.50(46.43)$ \\
\hline $\mathrm{T}_{2}$ & 150 & $10.00(18.39)$ & $32.50(34.75)$ & $47.50(43.57)$ & $58.50(49.90)$ \\
\hline $\mathrm{T}_{3}$ & 200 & $15.00(22.76)$ & $35.00(36.27)$ & $57.50(49.32)$ & $72.50(58.42)$ \\
\hline $\mathrm{T}_{4}$ & 250 & $22.26(28.14)$ & $47.50(43.57)$ & $65.50(54.04)$ & $85.50(67.69)$ \\
\hline $\mathrm{T}_{5}$ & Untreated control & $0.00(0.00)$ & $0.00(0.00)$ & $0.00(0.00)$ & $0.00(0.00)$ \\
\hline & SE \pm & 0.71 & 0.42 & 0.52 & 0.80 \\
\hline & CD at 5\% & 2.39 & 1.27 & 1.59 & 2.40 \\
\hline
\end{tabular}

*DAT: Days after treatment. **Figures in parentheses are arcsin transformed values.

Table 4: Median lethal concentration of $H$. indica for various larval instars of $P$. dionysius.

\begin{tabular}{|l|c|c|c|c|}
\hline $\begin{array}{c}\text { Larval instar of } \\
\text { P. dionysius }\end{array}$ & $\begin{array}{c}\mathrm{LC}_{50} \\
\left(\mathrm{IJs} \mathrm{m}^{-1} \text {.) }\right.\end{array}$ & $\begin{array}{c}\text { Fiducial } \\
\text { Limits }\end{array}$ & $\begin{array}{c}\text { Probit } \\
\text { equation }\end{array}$ & $\mathrm{X}^{2}$ value \\
\hline First instar & 44.15 & $27.72-58.79$ & $\mathrm{Y}=1.201 \mathrm{x}+3.024$ & 3.356 \\
\hline Second instar & 97.47 & $87.53-123.06$ & $\mathrm{Y}=1.631 \mathrm{x}+1.754$ & 0.038 \\
\hline Third instar & 150.12 & $116.70-180.04$ & $\mathrm{Y}=1.623 \mathrm{x}+1.476$ & 0.442 \\
\hline
\end{tabular}

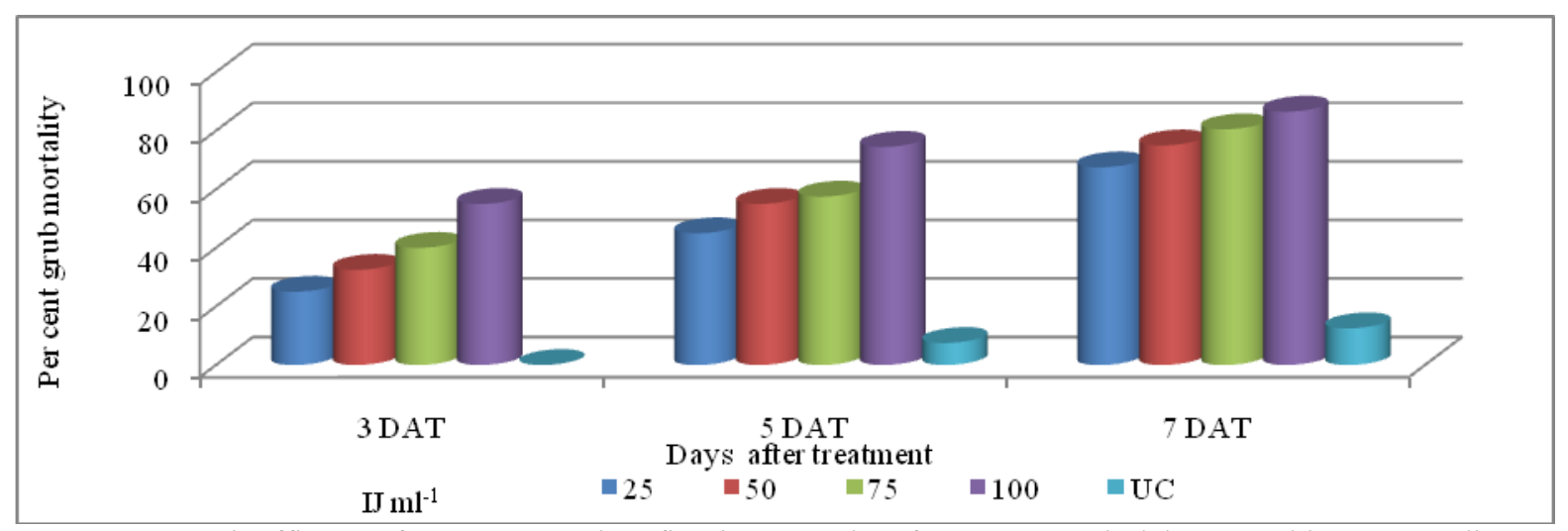

Figure 1: Bioefficacy of $H$. indica against first instar grubs of $P$. dionysius in laboratory bioassay studies

Volume 4 Issue 12, December 2015

\section{www.ijsr.net}




\section{International Journal of Science and Research (IJSR)}

ISSN (Online): 2319-7064

Index Copernicus Value (2013): 6.14 | Impact Factor (2014): 5.611

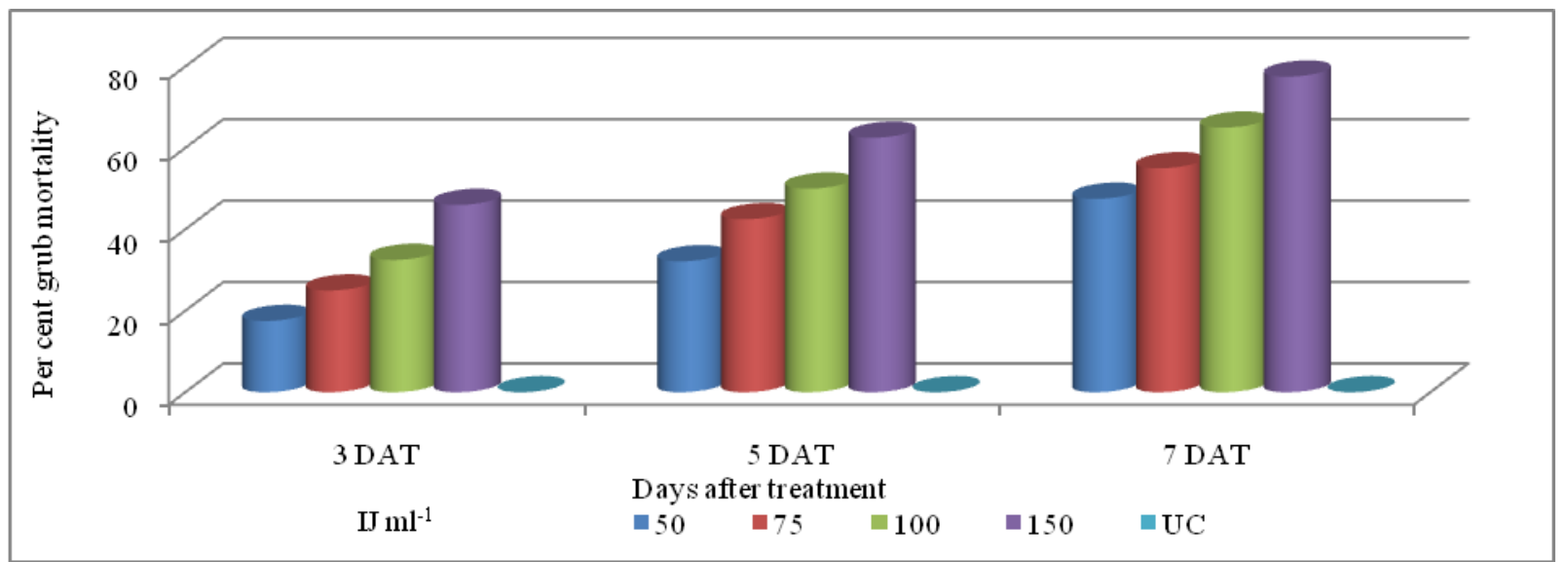

Figure 2: Bioefficacy of $H$. indica against second instar grubs of $P$. dionysius laboratory bioassay studies

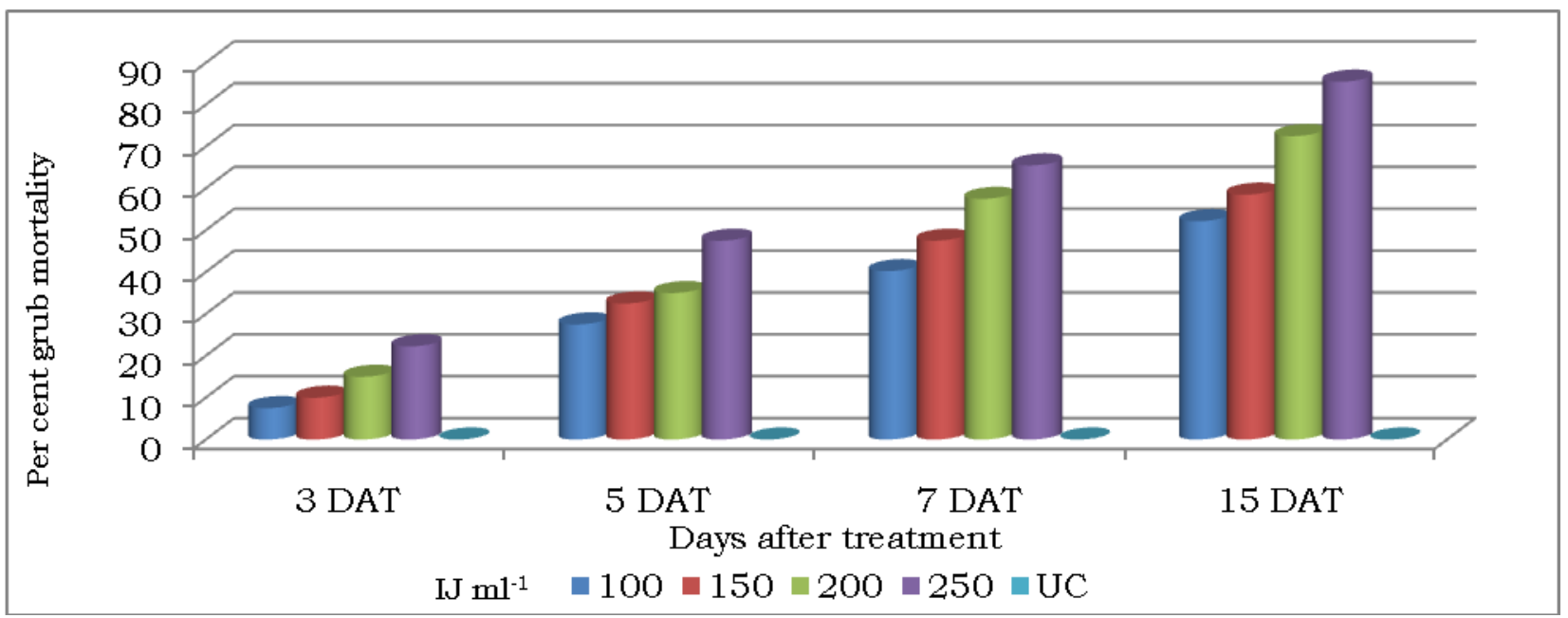

Figure 3: Bioefficacy of $H$. indica against third instar grubs of $P$. dionysius in laboratory bioassay studies.

\section{Acknowledgements}

This study was supported by College of Agriculture, Kolhapur, and Research Guid Dr. Pandurang B. Mohite Professor of Agricultural Entomology. Very very thanks to Dr. Pandurang B. Mohite, Dr. A. S. Bagde and Dr. G. G. Khot. Thanks very much to Dr. Sunanda Patil and NIPHM, Hydrabad (AP) who provided me Entomopathogenic nematodes for experiments.

\section{References}

[1] Abbott, W. S. 1925. A method of computing effectiveness of an insecticide. J. Econ. Entomol. 18: 265-267.

[2] Anonymous, 2015. Ministry of Agriculture Government of India. eands.dacnet.nic.in18022015. indiastat.com.

[3] Bhatnagar, A. 2011. Susceptibility of eggs, pupae and adults of white grub, Maladera insanabilis (Brenske) to the Entomopathogenic nematode (EPNs), Heterorhabditis bacteriophora Poinar. Indian Journal of Entomology. 73(4): 360-364.

[4] Bhawane, G.P., Mamlayya, A.B., Wagh, S.R. and Chaugule, A.K. 2012. Diversity of white grub beetles and their host range from Northern Wesetern ghats, Kolhapur district (MS) India. An International Quarirtly Jurnal of Life Science. 7(4): 589-596.

[5] David, H. and Nandagopal, V. 1986. Pests of sugarcane distribution, symptomatology of attack and identification Sugarcane Entomology in India, Sugarcane Breeding Institute (ICAR), Coimbatore Publication. pp. 1-29.

[6] FAO, 2011, FAO (Food and Agriculture Organization of United Nation) statistical data base (Internat website: www.fao.org)

[7] Finney, D.J. 1971. Probit Analysis. Cambridge Uni. Press, London. pp. 333.

[8] Gokce, C., Erbas, Z., Yilmaz, H., Demirbag, Z. and Demir, I. 2014. A new Entomopathogenic nematode species from Turkey, Steinernema websteri, and its virulence. Turk J. Biol. 38: 1-8.

[9] Grewal, P.S., Ehlers, R.U. and Shapiro-Ilan, D.I. 2005. Nematodes as biological control agents. Wallingford: CABI Publishing.

[10] Karunakar, G., Easwaramoorthy, S. and David H. 2000. Host - parasite interaction between two species of white grubs infesting sugarcane and two species of Entomopathogenic nematodes. SUGAR TECH (2000), 2(4): 12-16.

\section{Volume 4 Issue 12, December 2015}




\section{International Journal of Science and Research (IJSR) \\ ISSN (Online): 2319-7064}

Index Copernicus Value (2013): 6.14 | Impact Factor (2014): 5.611

[11] Kulkarni, N., Hussaini, S.S., Paunikar, S. and Joshi, K.C. 2008. Entomopathogenic nematodes in insect pest management of forestry and plantation crops: An appraisal. Indian I. Trop. Biodiv. 16: 155-166.

[12] Maneesakorn, P., An, R., Grewal, P. S. and Chandrapatya, A. 2010. Virulence of four new strains of Entomopathogenic nematodes from Thailand against second instar larva of Japanese beetle, Popillia japonica (Coleoptera: Scarabaeidae). Thai Journal of Agricultural Science. 43(2): 61-66.

[13] Mohite, 2014. Give attention to white grub incidence Agroplaning, Agroone July, 2014 pp.11.

[14] Patil, A.S., Shinde, V.D., Mager, S.B., Yadhav, R.G. and Nerkar, Y.S., 2004. Sugarcane woolly aphid (Ceratovacuna lanigera) its history and control measures. Proc. of Sugarcane Technologists Association in India pp.133-155. 